\title{
PERANAN DAN KONTRIBUSI SUB SEKTOR PERKEBUNAN DI PROVINSI JAMBI
}

\author{
Ahmad Soleh ${ }^{1}$
}

\begin{abstract}
The role of the sub plantation sector in developing the economy of the province of Jambi is no doubt already seen from the large number of residents who work and drape perekonomiannya in sub plantation sector. the data showed more than 60 percent of farmland in the province of Jambi is used as a plantation. The problem related goals of this research are (1) to analyze the development of the vast land, labor, and GRP sub plantation sector in the province of Jambi, (2) analyze contributions subplantation sector against the agricultural sector and GDP the province of Jambi, (3) analyze the effect of Extensive Land and labor against the Output of the Sub Sector Plantation Jambi province. The methods used in this research is descriptive qualitative and quantitative models by using regression Linear Regression and the contribution Multiplied by the method of OLS. The research results showed that (1) the development of land area, the workforce and GDP of sub sectors of the 2000-2015 period of Jambi province plantation continues to increase each year. (2) the variable land area and number of labor jointly or simultaneous affect GDP sub plantation sector province of Jambi. In the partial variable positive effect land area and significantly to GDP sub plantation sector province of Jambi. While labor has no effect significantly to GDP sub plantation sector province of Jambi.
\end{abstract}

Keyword:P DRB, Estates, Labor, Land Area

\section{PENDAHULUAN}

Di Provinsi Jambi sektor perkebunan merupakan salah satu sektor yang mempunyai peranan penting dalam pembangunan di Provinsi Jambi, yang ditunjukkan dari kontribusinya dalam PDRB. Dalam kesempatan ini saya ingin lebih menitik beratkan pada sub sektor perkebunan.

Sub sektor perkebunan merupakan salah satu sub sektor sebagai komponen dari sektor pertanian, sub sektor perkebunan tidak kalah pentingnya dari sub sektor-sub sektor lain pada sektor pertanian sebagai pembentuk PDRB. Berbagai komoditi yang dihasilkan oleh sub sektor perkebunan seperti karet, kelapa sawit, kelapa dalam, kulit kayumanis, kopi robusa dan lain sebagainya merupakan komoditi-komoditi yang dijadikan sebagai bahan baku industri dan diterima di pasar internasional. Sub

${ }^{1}$ STIE Muhammadiyah Jambi sektor perkebunan juga merupakan sub sektor pertanian yang secara tradisional merupakan salah satu penghasil devisa negara. Sebagian besar tanaman perkebunan tersebut merupakan usaha perkebunan rakyat, sedangkan sisanya diusahakan oleh perkebunan besar baik milik pemerintah maupun milik swasta (Soetrisno L. 1999).

Keberadaan lahan serta peranan tenaga kerja menentukan output sub sektor perkebunan. Atas dasar uraian di atas dengan mempertimbangkan kontribusi sub sektor perkebunan terhadap peningkatan pertumbuhan ekonomi di Provinsi Jambi maka penulis tertarik untuk melakukan penelitian dengan judul Analisis Sub Sektor Perkebunan Provinsi Jambi.

Penelitian ini bertujuan untuk Untuk mengetahui dan menganalisis perkembangan luas lahan, tenaga kerja, dan PDRB sub sektor perkebunan di Provinsi Jambi, menganalisis 
kontribusi sub sektor perkebunan terhadap sektor pertanian dan PDRB provinsi Jambi, Serta Untuk menganalisis pengaruh Luas Lahan dan Tenaga Kerja terhadap Output Sub Sektor Perkebunan Provinsi Jambi.

\section{TINJAUAN PUSTAKA}

\section{Produk Domestik Regional Bruto (PDRB)}

Produk Domestik Regional Bruto adalah jumlah nilai tambah barang dan jasa yang dihasilkn oleh seluruh unit usaha dalam suatu daerah tertentu dan merupakan nilai akhir barang dan jasa yang dihasilkan oleh sektor industry.

\section{Teori Produksi}

Produksi dapat dinyatakan sebagai perangkat prosedur dan kegiatan yang terjadi penciptaan komoditas berupa kegiatan usahatani maupun usaha lainnya. Sebelum di lakukan proses produksi di lahan, terlebih dahulu di lakukan proses pengadaan saprodi (sarana produksi) pertanian berupa industri agro-kimia (pupuk dan pestisida), industri agrootomotif (mesin dan peralatan pertanian), dan industri pembenihan dan pembibitan. Untuk proses produksi di lahan, dapat digunakan faktor-faktor produksi seperti lahan, tenaga kerja, modal, pupuk, pestisida, teknologi, serta manajemen.

\section{Fungsi Produksi}

Menurut Sadono Sukirno (2005), fungsi produksi secara matematis dapat digambarkan sebagai berikut:

$\mathbf{Q}=\mathbf{f}(\mathbf{K}, \mathbf{L}, \mathbf{R}, \mathbf{T})$

Dimana :

$\mathrm{K}=$ Jumlah stok modal atau persediaan modal

$\mathrm{L}=$ Jumlah tenaga kerja ( yang meliputi jenis tenaga kerja )

$\mathrm{T}=$ Tingkat teknologi yang digunakan

$\mathrm{R}=$ Biaya sewa lahan

$\mathrm{Q}=$ Jumlah produksi yang dihasilkan (Sukirno, 2005).

\section{Lahan dalam pertanian}

Luas lahan pertanian merupakan suatu yang sangat penting dalam proses produksi ataupun usaha tani dan usaha pertanian. Apabila luas lahan itu sempit maka sudah pasti kurang efisien dibandingkan lahan yang lebih luas.Semakin sempit lahan untuk usaha tani maka semakin tidak efisienlah usaha yang dilakukan.Namun dapat terjadi kecuali didukung oleh teknologi yang tepat karena tingkat efisiensi terletak pada penerapan teknologi.

\section{Tenaga Kerja}

Tenaga kerja terdiri dari angkatan kerja dan bukan angkatan kerja. Angkatan kerja (labor force) adalah penduduk yang bekerja dan penduduk yang belum pekerja namun siap untuk bekerja atau sendang mencari pekerjaan pada tingkat upah yang berlaku. Penduduk yang bekerja adalah mereka yang melakukan pekerjaan guna menghasilkan barang dan jasa untuk memperoleh penghasilan baik bekerja penuh maupun tidak bekerja penuh. Bukan angkatan kerja adalah mereka yang masih bersekolah, berumah tangga, penyandang cacat, dan lanjut usia.

\section{METODE PENELITIAN Jenis Data}

Data yang digunakan dalam penelitian ini adalah data sekunder dalam bentuk runtun waktu (time series) periode 2000 sampai dengan 2015. Adapun data yang digunakan adalah sebagai berikut :

1. PDRB Provinsi Jambi atas dasar harga konstan 2000 periode 20002015.

2. PDRB sektor pertanian provinsi Jambi atas dasar harga konstan 2000 periode 2000-2015.

3. PDRB sub sektor perkebunan provinsi Jambi atas dasar harga konstan 2000 periode 2000-2015. 
4. Luas lahan perkebunan Provinsi Jambi tahun 2000-2015.

5. Tenaga kerja sektor perkebunan provinsi Jambi tahun 2000-2015.

\section{Sumber Data}

Adapun data-data diperoleh yang digunakan dalam penelitian ini diperoleh dari instansi pemerintah, yaitu sebagai berikut :

1. Badan Pusat Statistik (BPS).

2. Dinas Perkebunan Provinsi Jambi.

3. Penelitian-Penelitian Terdahulu.

4. Artikel-artikel dan Sumber lainnya.

\section{Metode Analisis Data Analisis Kualitatif}

Analisis kuantitatif digunakan untuk melihat secara empiris sejauh mana pengaruh yang diberikan oleh Luas Lahan dan Jumlah Tenaga Kerja terhadap tingkat PDRB Sub Sektor Perkebunan. Peralatan statistik yang digunakan Persamaan Regresi Linier Berganda dengan metode OLS.

\section{Analisis Kuantitatif}

Analisis kuantitatif digunakan untuk melihat secara empiris sejauh mana pengaruh yang diberikan oleh Luas Lahan dan Jumlah Tenaga Kerja terhadap tingkat PDRB Sub Sektor Perkebunan. Peralatan statistik yang digunakan Persamaan Regresi Linier Berganda dengan metode OLS.

\section{Uji Asumsi Klasik}

\section{Uji Linearitas}

Uji ini bertujuan untuk menguji apakah model persamaan yang digunakan bersifat linear atau tidak, digunakan uji Ramsey Test. Linearitas suatu model dapat dilihat dengan membandingkan nilai f-statistik dari hasil olahan Ramsey Reset Test dengan F-tabel dan degree of freedom $(\mathrm{df}=\mathrm{n}-\mathrm{k}$ $=1$ ).

\section{Uji Normalitas}

Uji ini dimaksudkan untuk melihat apakah residualnya terdistribusi secara normal atau tidak sesuai dengan asumsi model regresi Best Linear Unbias Estimator (BLUE) dari klasik adalah dengan membandingkan nilai jarque-berra dengan nilai tabel Chi-square $\left(\mathrm{x}^{2}\right)$.

\section{Uji Autokorelasi}

Autokorelasi adalah korelasi (hubungan) yang terjadi antara anggota-anggota dari serangkaian pengamatan yang tersusun dalam rangkaian waktu (time series). Autokorelasi ini menunjukkan hubungan antara nilai-nilai yang berurutan dari variabel yang sama.

\section{Uji Heteroskedastisitas}

Uji heteroskedastisitas dilakukan untuk menguji apakah dalam sebuah model regresi terjadi ketidaksamaan varians dari residual pengamatan satu residual ke pengamatan lain tetap, maka telah terjadi heteroskedastisitas. Regresi yang baik adalah yang tidak terjadi heteroskedasttisitas.

\section{Uji Statistik}

Uji F Statistif

Nilai F hitung dapat dicari dengan rumus:

$\mathbf{F}=\frac{\mathbf{R}^{2} /(\mathbf{k}-1)}{\left(1-\mathbf{R}^{2}\right) /(\mathbf{n}-\mathbf{k})}$

Dimana:

$\mathrm{R}^{2} \quad$ : Koefisien determinasi

$\mathrm{K}$ : Jumlah parameter (jumlah variabel)

$\mathrm{N}$ : Jumlah sampel

k-1 : Derajat kebebasan

\section{Uji t Statistik}

Nilai t hitung dapat dicari dengan menggunakan formula:

$$
\mathbf{t}=\frac{\mathbf{b i}}{\text { se }(\mathbf{b i})}
$$

Dimana:

$$
\begin{array}{ll}
\mathrm{t} & : \text { Nilai t-hitung } \\
\mathrm{bi} & \text { : Koefisien Regresi }
\end{array}
$$


se (bi) : Kesalahan standar yang $\mathrm{R}^{2}$ : Koefisien determinasi.

ditaksir

$(\mathrm{Y}-\overline{\mathrm{y}})^{2}:$ Kuadrat nilai $\mathrm{Y}$ riil dengan

\section{Koefisien Determinasi $\left(\mathbf{R}^{2}\right)$}

Untuk mengetahui besarnya persentase pengaruh variabel bebas (indevendent variable) terhadap variabel terikat (dependent variable) digunakan koefisien dengan rumus:

$$
\mathbf{R}^{2}=\mathbf{1}-\frac{\Sigma(\mathbf{Y}-\overline{\mathbf{y}})^{2}}{\Sigma(\mathbf{Y}-\overline{\mathbf{y}})^{2}}
$$
nilai Y prediksi.

$(\mathrm{Y}-\overline{\mathrm{y}})^{2}$ : Kuadrat nilai selisih $\mathrm{Y}$ riil dengan nilai Y rata-rata.

\section{HASIL PENELITIAN}

Analisis Perkembangan Luas Lahan, Tenaga Kerja dan PDRB Sub Sektor Perkebunan di Provinsi Jambi

Dimana:

Data Perkembangan Luas Lahan Sub Sektor Perkebunan di Provinsi Jambi

\begin{tabular}{|c|c|c|}
\hline PERIODE & $\begin{array}{l}\text { JAS LAHAN } \\
\text { (HA) }\end{array}$ & PERKEMBANGAN (\%) \\
\hline 2000 & 1.091 .141 & - \\
\hline 2001 & 1.099 .801 & 0,79 \\
\hline 2002 & 1.103 .319 & 0,32 \\
\hline 2003 & 1.124 .349 & 1,91 \\
\hline 2004 & 1.152 .278 & 2,48 \\
\hline 2005 & 1.238 .962 & 7,52 \\
\hline 2006 & 1.265 .025 & 2,10 \\
\hline 2007 & 1.298 .075 & 2,61 \\
\hline 2008 & 1.349 .558 & 3,97 \\
\hline 2009 & 1.352 .318 & 0,20 \\
\hline 2010 & 1.382 .205 & 2,21 \\
\hline 2011 & 1.404 .558 & 1,62 \\
\hline 2012 & 1.470 .913 & 4,72 \\
\hline 2013 & 1.479 .461 & 0,58 \\
\hline 2014 & 1.551 .426 & 4,86 \\
\hline 2015 & 1.580 .733 & 1,89 \\
\hline \multicolumn{2}{|c|}{ Rata rata } & 2,52 \\
\hline
\end{tabular}

Sumber : Dinas Perkebunan Provinsi Jambi (Data Olahan)

\section{Grafik Perkembangan Jumlah Tenaga Kerja Sub Sektor Perkebunan di} Provinsi Jambi

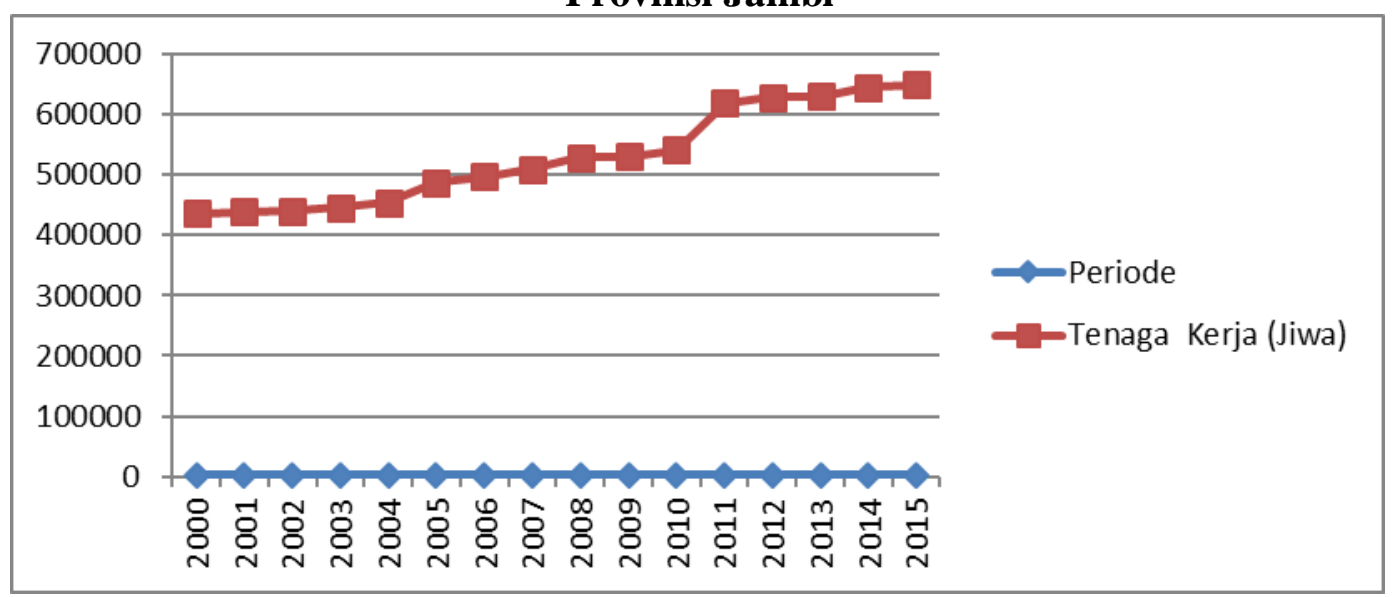


Grafik Perkembangan PDRB Sub Sektor Perkebunan di Provinsi Jambi

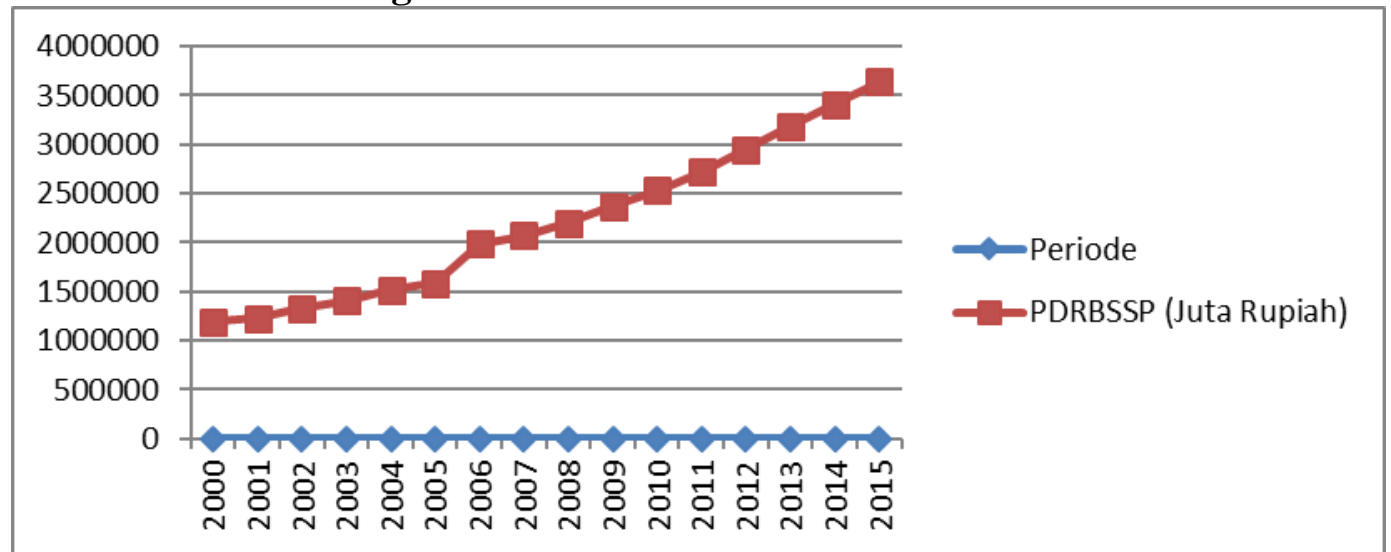

Kontribusi PDRB Sub Sektor sumbangan sub sektor perkebunan Perkebunan Terhadap PDRB Sektor terhadap perekonomian wilayah yang Pertanian dan PDRB Provinsi Jambi

Kontribusi sub sektor perkebunan terhadap PDRB sektor pertanian dan PDRB Provinsi Jambi menggambarkan peranan sub sektor perkebunan dalam pembentukan PDRB sektor pertanian. Kontribusi pendapatan perkebunan merupakan sesuatu gambaran tentang terangkum dalam PDRB Provinsi Jambi. Semakin besar PDRB sub sektor perkebunan dalam perekonomian Provinsi Jambi maka diharapkan kontribusinya terhadap pembentukan PDRB sektor pertanian Provinsi Jambi akan semakin besar dan begitu pula sebaliknya.

Kontribusi PDRB Sub Sektor Perkebunan Terhadap PDRB Sektor Pertanian

\begin{tabular}{cccc}
\hline Periode & $\begin{array}{c}\text { PDRB Sub Sektor } \\
\text { Perkebunan (Juta } \\
\text { Rupiah) }\end{array}$ & $\begin{array}{c}\text { PDRB Sektor } \\
\text { Pertanian (juta } \\
\text { Rupiah) }\end{array}$ & $\begin{array}{c}\text { Kontribusi Sub Sektor } \\
\text { Perkebunan } \\
\text { Terhadap Sektor } \\
\text { Pertanian (\%) }\end{array}$ \\
\hline 2000 & 1.190 .525 & 3.168 .557 & 37,57 \\
2001 & 1.224 .954 & 3.286 .182 & 37,28 \\
2002 & 1.331 .451 & 3.445 .511 & 38,64 \\
2003 & 1.409 .277 & 3.568 .015 & 39,50 \\
2004 & 1.516 .507 & 3.749 .356 & 40,45 \\
2005 & 1.588 .829 & 3.922 .075 & 40,51 \\
2006 & 1.989 .267 & 4.366 .677 & 45,56 \\
2007 & 2.072 .373 & 4.566 .134 & 45,39 \\
2008 & 2.197 .097 & 4.827 .241 & 45,51 \\
2009 & 2.368 .323 & 5.148 .546 & 46,00 \\
2010 & 2.531 .684 & 5.412 .392 & 46,78 \\
2011 & 2.722 .741 & 5.742 .052 & 47,42 \\
2012 & 2.948 .764 & 6.178 .408 & 47,73 \\
2013 & 3.186 .854 & 6.636 .219 & 48,02 \\
2014 & 3.409 .598 & 7.134 .614 & 47,79 \\
2015 & 3.642 .385 & 7.517 .274 & 48,45 \\
& Rata-rata & & 43,91 \\
\hline
\end{tabular}

Sumber : Badan Pusat Statistik Provinsi Jambi data diolah 


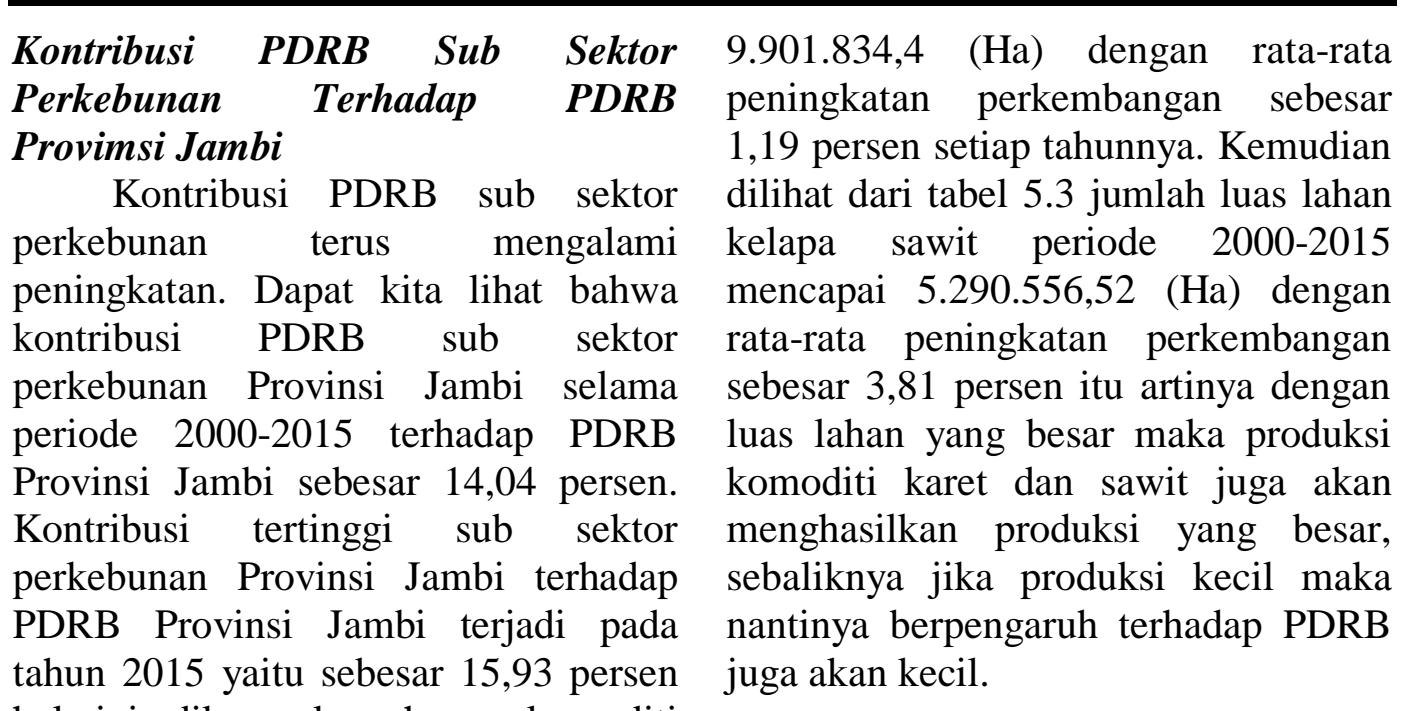
hal ini dikarenakan harga komoditi perkebunan meningkat sehingga produksi meningkat. Sedangkan kontribusi terkecil sub sektor perkebunan terhadap PDRB Provinsi Jambi yaitu tahun 2001 dengan kontribusi sebesar 11,18 persen. Kontribusi terkecil dari komoditas perkebunan yaitu komoditi lada dengan jumlah luas lahan sebesar 2.788,2 (Ha) dengan perkembangan luas lahan lada sebesar 0,87 persen. Hal ini dikarenakan adanya konversi lahan oleh para petani menjadi komoditi yang lainnya dengan hasil produksi dan daya jual yang lebih besar. Sedangkan kontribusi terbesar dari komoditi perkebunan yaitu komoditi karet dan disusul oleh komoditi kelapa sawit. Dapat dilihat dari tabel 5.2 jumlah luas lahan periode 2000-2015 mencapai Ramsey RESET Test

Equation: UNTITLED

Specification: LOGPDRBSSP C LOGLL LOGTK

Omitted Variables: Squares of fitted values

\begin{tabular}{lccc}
\hline \hline & Value & df & Probability \\
\cline { 2 - 4 } t-statistic & 0.396414 & 12 & 0.6988 \\
F-statistic & 0.157144 & $(1,12)$ & 0.6988 \\
Likelihood ratio & 0.208166 & 1 & 0.6482 \\
\hline \hline
\end{tabular}

Sumber: hasil output regresi eviews 9.0

Berdasarkan data diatas dapat dilihat bahwa nilai prob $\mathrm{F}$ hitung sebesar $0,6988>0,05$, maka dapat

\section{Analisis Pengaruh Luas Lahan dan} Tenaga Kerja terhadap Output Sub Sektor Perkebunan Provinsi Jambi.

Dari hasil analisis di atas dapat dilhat besarnya koefisien luas lahan sub perkebunan sebesar 2.488961. Sedangkan koefisien jumlah tenaga kerja sub sektor perkebunan sebesar 0.397616. Besarnya return to scale dapat dihitung dengan menjumlahkan koefisien masing-masing variabel independen $(2.488961+0.397616=$ 2.886577) yang menunjukkan bahwa sub sektor Perkebunan di Provinsi Jambi berada pada kondisi increasing return to scale.

\section{Pengujian Asumsi Klasik \\ Uji Linearitas \\ Hasil Uji Linearitas}




\section{Hasil uji normalitas}

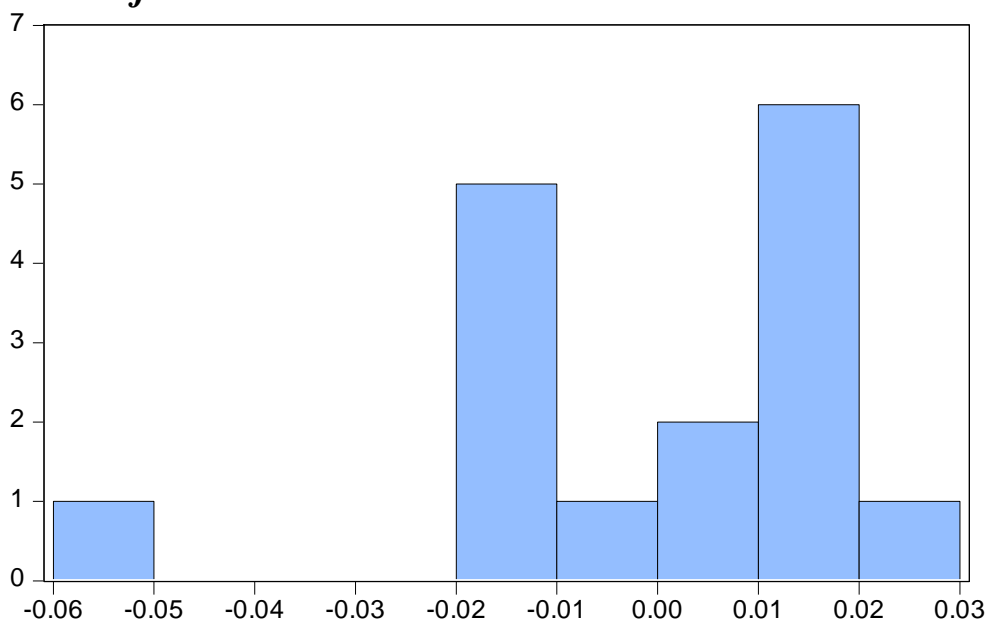

Series: Residuals

Sample 20002015

Observations 16

Mean $\quad 1.11 \mathrm{e}-15$

Median $\quad 0.006519$

Maximum $\quad 0.020924$

Minimum $\quad-0.050577$

Std. Dev. $\quad 0.019767$

Skewness $\quad-1.016943$

Kurtosis $\quad 3.502430$

Jarque-Bera 2.926084

Probability $\quad 0.231531$

Sumber: hasil output regresi eviews 9.0

Berdasarkan data diatas dapat

lihat bahwa nilai Prob Jarque-Bera hitung sebesar 0,231531>0,05, maka

Uji Autokorelasi

Hasil Uji Autokorelasi

model ini lolos dari ketidaknormalan

disstribusi residual.

Breusch-Godfrey Serial Correlation LM Test:

\begin{tabular}{lll}
\hline \hline F-statistic & 1.669767 Prob. F(2,11) & 0.2327 \\
Obs*R-squared & 3.726241 Prob. Chi-Square(2) & 0.1552 \\
\hline
\end{tabular}

$\overline{\text { Sumber: hasil output }}=\overline{\overline{\text { egresi eviews } 9.0}}=$

Pada hasil uji Breusch-Godfrey ini diketahui bahwa nilai Probabilitas Chi-Square sebesar $0,1552>\alpha$. Dimana $\alpha=5 \%$ atau 0,05 . Berdasarkan Perbandingan tersebut masalah autokorelasi pada model yang digunakan.

\section{Uji Heteroskedastisitas \\ Hasil Uji Heteroskedastisitas} dapat diambil kesimpulan tidak ada Heteroskedasticity Test: White

\begin{tabular}{lll}
\hline \hline F-statistic & 0.581469 Prob. F(3,12) & 0.6384 \\
Obs*R-squared & 2.030683 Prob. Chi-Square(3) & 0.5661 \\
Scaled explained SS & 1.677339 Prob. Chi-Square(3) & 0.6420 \\
\hline \hline
\end{tabular}

Sumber: hasil output regresi eviews 9.0

Dari Tabel menunjukkan bahwa uji white menghasilkan kesimpulan tidak ada masalah heteroskedastisitas, hal ini dibuktikan dengan nilai Obs*R-

Variance Inflation Factors squared 2.030683 dengan prob 0.5661 , maka $0.5661>0,05$.

\section{Uji Multikolinearitas \\ Hasil Uji Multikolinearitas}

Date: 01/22/18 Time: 01:17

Sample: 20002015

Included observations: 16 


\begin{tabular}{cccc}
\hline \hline & \multicolumn{2}{c}{ Coefficient } & Uncentered \\
Variable & Variance & VIF & VIF \\
\hline \hline C & 0.681162 & 24173.83 & NA \\
LOGLL & 0.226579 & 300579.4 & 22.59786 \\
LOGTK & 0.160495 & 186380.1 & 22.59786 \\
\hline \hline
\end{tabular}

Sumber: data diolah dengan eviews 9.0

Dari tabel dapat dilihat bahwa terdapat variabel yang memiliki nilai lebih dari 10, sehingga dapat disimpulkan diduga terjadi multikolinearitas diantara variabel bebas dalam model regresi.

\section{Uji Statistik}

\section{Uji F}

Untuk mengetahui apakah variabel Luas Lahan dan Jumlah Tenaga Kerja secara bersamasama/simultan berpengaruh terhadap Output Sub Sektor Perkebunan di Provinsi Jambi dilakukan dengan uji F. Dengan nilai F-tabel untuk $\alpha=5 \%$ $(0,05)$ dan d.f 3;16 diperoleh nilai $F$ tabel sebesar 3,81 , sedangkan nilai $\mathrm{F}$ hitung yang diperoleh sebesar 434.7065. Nilai F hitung lebih besar daripada $\mathrm{F}$ tabel, sehingga keputusan yang diambil adalah menolak $\mathrm{H}_{0}$ dan menerima $\mathrm{H}_{\mathrm{a}}$.Artinya variabel Luas Lahan dan Jumlah Tenaga Kerja secara bersama-sama berpengaruh signifikan terhadap perubahan Output Sub Sektor Perkebunan di Provinsi Jambi.

\section{Uji T}

Berdasarkan hasil perhitungan yang telah dilakukan diperoleh nilai thitung untuk masing variabel dependen Luas Lahan dan Jumlah Tenaga Kerja sebesar 4.397627 dan 1.933485. Pada variabel Luas Lahan nilai t-hitung lebih besar daripada nilai t-tabel. Maka keputusan yang diambil adalah menolak $\mathrm{H}_{0}$ dan menerima $\mathrm{H}_{\mathrm{a}}$. Hal tersebut menunjukkan tingkat Luas Lahan berpengaruh signifikan terhadap Output Sub Sektor Perkebunan. Pada variabel Jumlah Tenaga Kerja nilai thitung Jumlah Tenaga Kerja lebih besar daripada nilai t-tabel. Maka keputusan yang diambil adalah menolak $\mathrm{H}_{0}$ dan menerima $\mathrm{H}_{\mathrm{a}}$. Hal tersebut menunjukkan Jumlah Tenaga Kerja berpengaruh signifikan terhadap Output Sub Sektor Perkebunan.

\section{Koefisien Determinasi $\left(R^{2}\right)$}

Pada perhitungan statistik diperoleh besarnya koefisien determinasi $\left(\mathrm{R}^{2}\right)$ sebesar 0.985268 . Hal ini menunjukkan bahwa Output Sub Sekor Perkebunan di Provinsi Jambi mampu dijelaskan oleh Luas Lahan dan Jumlah Tenaga Kerja sebesar 98,53\%, sedangkan sisanya sebesar $1,47 \%$ dipengaruhi oleh faktor lain yang tidak dijelaskan dalam penelitian.

\section{SIMPULAN}

1. Perkembangan luas lahan, tenaga kerja dan PDRB sub sektor perkebunan Provinsi Jambi periode 2000-2015 terus mengalami peningkatan setiap tahunnya. Ratarata perkembangan luas lahan sub sektor perkebunan Provinsi Jambi adalah sebesar 2,52\%. Tenaga kerja sub sektor perkebunan mengalami perkembangan setiap tahunnya dengan rata-rata perkembangan sebesar 2,74 \%. PDRB sub sektor perkebunan mengalami perkembangan dengan rata-rata sebesar 7,84\%.

2. Kontribusi PDRB sub sektor perkebunan terhadap PDRB pertanian terus meningkat dengan rata-rata peningkatan sebesar 43,91 
$\%$. Sedangkan kontribusi PDRB sub sektor perkebunan terhadap PDRB Provinsi Jambi juga terus meningkat setiap tahunnya dengan rata-rata peningkatan sebesar $14,04 \%$.

3. Berdasarkan hasil perhitungan regresi, variabel luas lahan dan jumlah tenaga kerja secara bersamasama atau simultan mempengaruhi PDRB sub sektor perkebunan provinsi Jambi. Secara parsial variabel luas lahan berpengaruh positif dan signifikan terhadap PDRB sub sektor perkebunan provinsi Jambi. Sedangkan Tenaga kerja tidak berpengaruh signifikan terhadap PDRB sub sektor perkebunan Provinsi Jambi.

\section{Saran}

1. Bagi pihak yang ingin melakukan penelitian selanjutnya tentang sub sektor perkebunanbisamencoba menggunakan variabel lain yang belum dijelaskan pada penelitian ini dan penggunaan pendekatan lain untuk mendapatkanhasil yang lebih baik.

2. Bagi pemerintah daerah Provinsi Jambi sebaiknya meningkatkan kerjasama dengan masyarakat untuk mengoptimalkan segala potensi pada sub sektor perkebunan provinsi Jambi guna memaksimalkan output sub sektor perkebunan di Provinsi Jambi.

\section{DAFTAR PUSTAKA}

Arsyad, 1993, Ekonomi Pembangunan Edisi Ketiga, STIE YKPN, Yogyakarta

-------, 1989, Konservasi tanah dan air, IPB Perss, Bogor.

Gilarso, 1992, Pembangunan Ekonomi Indonesia, Ghalia, Jakarta.

Hempel dan Pauly, 2010, Ekonomi Perikanan Teori kebijakan dan pengolahan, Gramedia Pustaka Utama, Jakarta.
Jhingan, 1993, Ekonomi Pembangunan dan Perencanaan, Rajawali Pers, Jakarta. -, 1998, Ekonomi Pembangunan dan Perencanaan, Diterjemahkan Oleh D. Guritno, Rajawali Pers, Jakarta.

Lackey, 2005. Ekonomi Perikanan Teori, Kebijakan dan Pengelolaan, GM, Jakarta.

Mubyarto, 1989, Pengantar Ekonomi Pertanian, LP3ES, Jakarta. 1977. Pengantar Ekonomi Pertanian, Intermasa, Jakarta.

Rismadani, 2015. Pengaruh Tentang Tenaga Kerja, Jumlah Produksi dan Luas Lahan Dari Produk Domestik Bruto Sektor Pertanian di Provinsi Sumatera Barat.

Sutrisno L, 1999. Kelapa Sawit : Kajian Sosial Ekonomi, Aditiya, P3PK UGM, Yogyakarta.

Sukirno, Sadono, 2002. Pengantar Teori Makro Ekoomi, Jakarta Raja Grafindo Persada.

Tarigan, R, 2005. Perencanaan Pembangunan Wilayah, Bumi Aksara, Jakarta.

Thessa, 2013. Pengaruh Pengeluaran Pemerintah, Luas Lahan, irigasi dan Tenaga Kerja Pertanian di Sektor Pertanian Terhadap Produk Domestik Bruto (PDB).

Todaro MP,1998.Pembangunan Ekonomi dunia Ke Tiga, Erlangga, Jakarta. 